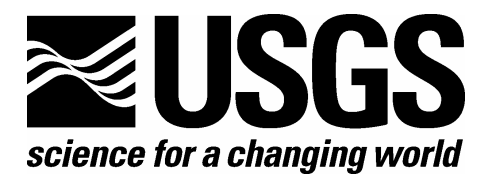

This report was produce in cooperation with the Department of Energy through the Interagency Agreement DE-Al52-01NV13944

\title{
Inversion of Gravity Data to Define the Pre-Cenozoic Surface and Regional Structures Possibly Influencing Groundwater Flow in the Rainier Mesa Region, Nye County, Nevada
}

By Thomas G. Hildenbrand, Geoffrey A. Phelps, and Edward A. Mankinen

2006

Open File Report 2006-1299

U.S. Department of the Interior

U.S. Geological Survey 


\section{U.S. Department of the Interior DIRK KEMPTHORNE, Secretary}

\section{U.S. Geological Survey \\ Mark Myers, Director}

U.S. Geological Survey, Reston, Virginia 2006

Revised and reprinted: 2006

For product and ordering information:

World Wide Web: http://www.usgs.gov/pubprod

Telephone: 1-888-ASK-USGS

For more information on the USGS-the Federal source for science about the Earth, its natural and living resources, natural hazards, and the environment:

World Wide Web: http://www.usgs.gov

Telephone: 1-888-ASK-USGS

Suggested citation:

Hildenbrand, T.G., Phelps, G.A., and Mankinen, E.A., 2006, Inversion of gravity data to define the pre-Cenozoic surface and regional structures possibly influencing groundwater flow in the Rainier Mesa Region, Nye County, Nevada: U.S. Geological Survey Open-File Report 2006-1299, 29 p. http://pubs.usgs.gov/of/2006/1299/

Any use of trade, product, or firm names is for descriptive purposes only and does not imply endorsement by the U.S. Government.

Although this report is in the public domain, permission must be secured from the individual copyright owners to reproduce any copyrighted material contained within this report. 


\section{Contents}

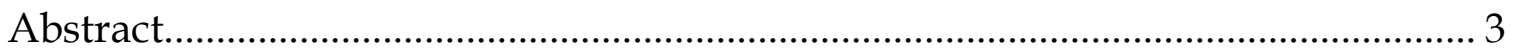

Introduction

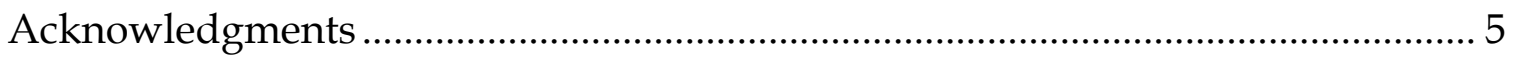

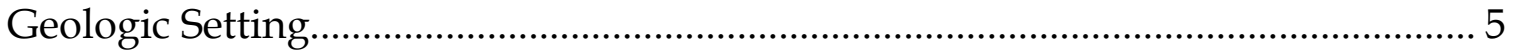

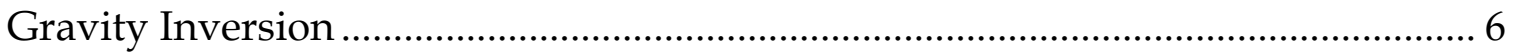

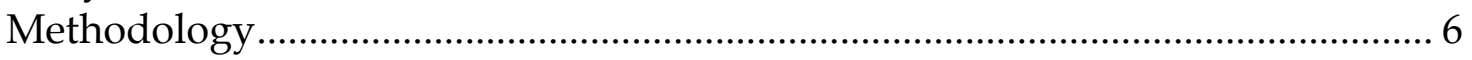

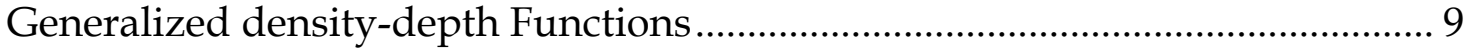

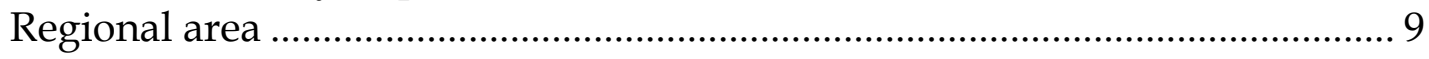

Yucca Flat, Timber Mountain, and Pahute Mesa areas ................................. 10

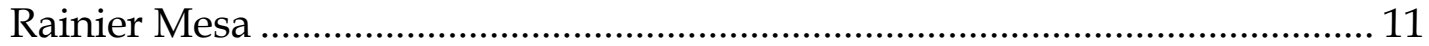

Composite Thickness Map and Resulting Accuracy ........................................ 12

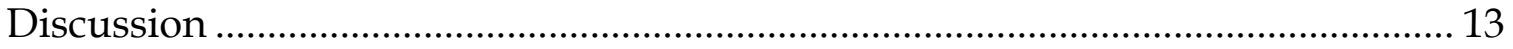

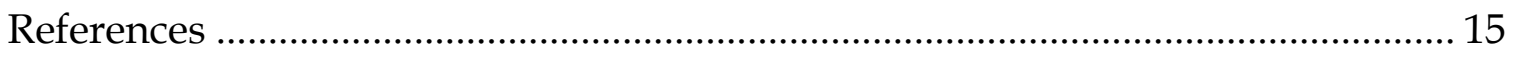

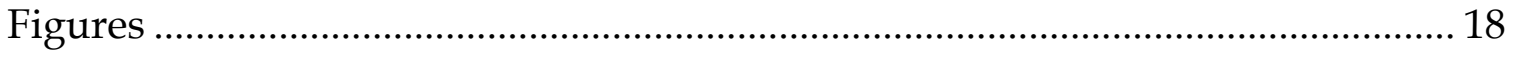




\section{Abstract}

A three-dimensional inversion of gravity data from the Rainier Mesa area and surrounding regions reveals a topographically complex pre-Cenozoic basement surface. This model of the depth to pre-Cenozoic basement rocks is intended for use in a 3D hydrogeologic model being constructed for the Rainier Mesa area. Prior to this study, our knowledge of the depth to pre-Cenozoic basement rocks was based on a regional model, applicable to general studies of the greater Nevada Test Site area but inappropriate for higher resolution modeling of ground-water flow across the Rainier Mesa area. The new model incorporates several changes that lead to significant improvements over the previous regional view. First, the addition of constraining wells, encountering old volcanic rocks lying above but near pre-Cenozoic basement, prevents modeled basement from being too shallow. Second, an extensive literature and well data search has led to an increased understanding of the change of rock density with depth in the vicinity of Rainier Mesa. The third, and most important change, relates to the application of several depth-density relationships in the study area instead of a single generalized relationship, thereby improving the overall model fit. In general, the pre-Cenozoic basement surface deepens in the western part of the study area, delineating collapses within the Silent Canyon and Timber Mountain caldera complexes, and shallows in the east in the Eleana Range and Yucca Flat regions, where basement crops out. In the Rainier Mesa study area, basement is generally shallow $(<1 \mathrm{~km})$. The new model identifies previously unrecognized structures within the pre-Cenozoic basement that may influence groundwater flow, such as a shallow basement ridge related to an inferred fault extending northward from Rainier Mesa into Kawich Valley.

\section{Introduction}

Underground nuclear tests at the Nevada Test Site from 1951 to 1992 introduced highly toxic contaminants into the ground-water system, which are presently migrating south from Pahute Mesa (Laczniak and others, 1996; Russell and Locke, 1996; Kersting and others, 1999). The Pahute Mesa and Rainier Mesa underground test areas in the northwestern part of the Nevada Test Site (NTS, fig. 1) were the sites of 85 and 61 tests, respectively (U.S. Department of Energy, 1994). 
Rainier Mesa, a southeast extension of Pahute Mesa (fig. 1), is a highland of volcanic rocks overlying denser, pre-Cenozoic sedimentary carbonate and siliceous rocks and felsic and intermediate plutonic basement rocks. It lies between Yucca Flat to the east and the Silent Canyon and Timber Mountain caldera complexes to the west. The selected Rainier Mesa study area (red line, fig. 1) encompasses the Rainier Mesa and Shoshone Mountain Corrective Action Units, regions designated for detailed study by the Department of Energy. Gravity anomalies within the study area (fig. 2) suggest a complex basement surface, the result of transitioning from Basin and Range faulting of Yucca Flat to the collapse structures of Silent Canyon caldera and Timber Mountain caldera complexes.

In the present study, we build on previous geophysical studies by Hildenbrand and others (1999), McKee and others (1999), and Phelps and others (1999) that inverted gravity data to generate a three-dimensional view of the basement surface, defined as the contact between pre-Cenozoic and younger rocks. The goal of the previous studies, as in this study, was to define the interface between the dense pre-Tertiary rocks (e.g., Mesozoic granitoids, Paleozoic and Precambrian carbonate and siliceous sedimentary rocks) and the less dense Tertiary and Quaternary rocks and sediments. This interface is important because it defines the unconformity between the basin rocks and sediments with either carbonate rocks belonging to regional carbonate aquifers, or silicic rocks belonging to regional confining units. These regional rock packages significantly influence the groundwater flow within and between basins of the region. Additionally, in the western Rainier Mesa region many of the overlying Tertiary volcanic rocks are aquifers (Laczniak and others, 1996), and their overall thickness provides important insights on structures possibly influencing ground-water flow.

To a first order, gravity anomalies in our study area (fig. 2) reflect variations in the thickness of low-density sedimentary and volcanic rocks above denser pre-Tertiary rocks. The gravity data can therefore be used to model the depth to the pre-Tertiary rocks by estimating the density-depth relationship of the rocks within and around the basin. The previous geophysical studies mentioned above each developed a model of the depth to the pre-Tertiary rocks using density-depth relationships customized according to the rock stratigraphy in their respective study areas. We adopt these earlier results, whose study 
areas partially lie within the current study area, but improve on the modeling method by incorporating and merging these results and by utilizing a more representative depthdensity relationship for the Rainier Mesa area than the ones previously used.

\section{Acknowledgments}

Rick Blakely and Victoria Langenheim, USGS colleagues, and Alan Gogbill and Gayle Pawloski, Members of the DOE Geologic Subcommittee of the Technical Working Group, as reviewers and consulting colleagues, provided valuable suggestions related to both the technical and applied aspects of this study, leading to a greatly improved paper. We are also grateful to Sig Drellack, Lance Prothro, Margaret Townsend, and Leigh Justet for providing critical borehole density and geologic data. The Department of Energy through the Interagency Agreement DE-AI52-01NV13944 funded this project.

\section{Geologic Setting}

The study area (fig. 1) lies within the northern part of the Nevada Test Site, where Precambrian crystalline rocks underlie a thick sequence (as much as $8 \mathrm{~km}$ ) of latePrecambrian and Paleozoic sedimentary rocks. These rocks are intruded by Jurassic and Cretaceous granitic rocks, especially to the west near the California-Nevada border. Mesozoic compressional deformation produced folds and faults of all types, including regional thrust faults (Armstrong, 1968). In the Miocene (specifically 16-7 Ma) southwestern Nevada experienced pronounced volcanism over an area of $>10,000 \mathrm{~km}^{2}$, known as the SW Nevada volcanic field (SNVF, Christiansen and others, 1977), where ash-flow tuffs and lava flows reach thicknesses locally of several kilometers. The Miocene ash-flow sheets and lava flows of the southwest Nevada volcanic field were deposited on the complexly deformed basement of Mesozoic granitic rocks and Paleozoic and Precambrian sedimentary and metamorphic rocks (Slate and others, 1999).

During Miocene magmatic events, a series of overlapping calderas developed in the SNVF that includes the Silent Canyon and Timber Mountain caldera complexes (Nobel and others, 1991; Sawyer and others, 1994). A relatively dense, shallow resurgent dome is associated with the Timber Mountain caldera complex (Kane and others, 1981). Voluminous sheets of welded and non-welded ash-flow tuff and numerous lava flows erupted from volcanic centers associated with caldera structures, and thus the calderas serve as major aquifers and confining units within the Rainier Mesa area (Laczniak and 
others, 1996). Thus knowledge of the thickness of the caldera fill and identification of caldera structures are important in our understanding of the ground-water flow system. For example, a step or an abrupt shallowing of pre-Cenozoic basement may represent a structural barrier or conduit channeling groundwater and generating a steep hydrologic gradient.

\section{Gravity Inversion}

\section{Methodology}

The isostatic residual gravity field in figure 2 is based on 4930 existing gravity measurements (black circles, fig. 3) and 39 new gravity stations (magenta circles; unpublished data, Robert Morin, U.S. Geological Survey, written communication, 2005). The overall distribution of gravity stations is about 4.6 stations within $1 \mathrm{~km}^{2}$ on the average. Although dense coverage exists within Yucca Flat, gravity stations are more widely spaced in remaining parts of the study area. Gravity data were reduced using the Geodetic Reference System of 1967 and referenced to the International Gravity Standardization Net 1971 gravity datum (Morelli and others, 1974; see also Mankinen and others (1998) for details on reducing the data to complete Bouguer anomaly values). The isostatic residual anomaly was calculated using a reduction density of $2,670 \mathrm{~kg} / \mathrm{m}^{3}$, crustal thickness of $30 \mathrm{~km}$, and a mantle-crust density contrast of $350 \mathrm{~kg} / \mathrm{m}^{3}$ (see Simpson and others, 1986). All data were gridded at a spacing of $1 \mathrm{~km}$ using a minimum curvature algorithm of Webring (1982).

To first order, the isostatic residual gravity field reflects the pronounced contrast between dense, pre-Cenozoic rocks (about 2,670 kg/ $\mathrm{m}^{3}$ ) and significantly

lower-density volcanic caldera fill (Healey, 1968; Grauch and others, 1999). The gravity low over the Silent Canyon caldera region is one of the most prominent lows in the western U.S., suggesting an unusually thick accumulation of low-density volcanic rocks. Higher residual isostatic gravity anomalies occur over outcrops of relatively dense Paleozoic rocks, such as in the Eleana Range (Slate and others, 1999).

Using the gravity inversion method derived by Jachens and Moring (1990; modified to include drill hole data; Bruce Chuchel, U.S. Geological Survey, written communication, 1997), we separated the isostatic residual gravity anomaly into two components: a basin gravity field and a basement gravity field. The basin gravity field reflects variations in 
the thickness of low-density Cenozoic volcanic and sedimentary rocks. The basement gravity field reflects changes in density related to lithologic variations within the denser pre-Cenozoic rocks. To reduce edge effects, the area of the inversion extended well beyond the area shown in figure 2 (from lat. $36^{\circ} 30^{\prime}$ to $37^{\circ} 30^{\prime}$ and from long. $115^{\circ} 52.2^{\prime}$ to $\left.117^{\circ}\right)$.

The inversion allows the density of pre-Cenozoic basement rocks to vary horizontally, but the densities of basin-filling deposits are fixed using a representative density-versusdepth relationship. Wells that extended to basement rocks constrain the calculations (yellow circles, fig. 4; Bechtel, Nevada, written communication, 2005). Additionally, fourteen drill holes (green circles, fig. 4; Bechtel, Nevada, written communication, 2005) bottomed in older volcanic rocks (i.e., lying above but very near pre-Cenozoic basement such as Oak Springs Butte confining unit) and provided a means to constrain depths of basement by adding $\sim 300 \mathrm{~m}$ (based on the depth relationship of the stratigraphic layer at the bottom of the drill hole with pre-Cenozoic basement rocks; Ted McKee, U.S. Geological Survey, oral communication, 2006) to the total depth of the well as an estimate of basement depth (discussed below). Two locations in the model were artificially fixed using fictitious drill hole basement intercepts. In these areas instabilities in the gravity inversion generated geologically unreasonable results. One fictitious well near the Silent Canyon caldera complex (green circle with a white X, fig. 4) was adopted from Hildenbrand and others (1999), who constrained basement depth in the SE region of the caldera where control on basement depth is absent. They selected a depth estimate ( 2 $\mathrm{km})$ at this location, based on projection of the geology at the bottom of several nearby drill holes to a pre-Cenozoic depth (Ted McKee, U.S. Geological Survey, oral communication, 1999). In a similar fashion, we also fixed basement depth at about lat. $37^{\circ} 10^{\prime}$ and long. $116^{\circ} 15^{\prime}$ to avoid unrealistic results. The inversion estimated thicknesses greater than $5 \mathrm{~km}$ over a 36-km2 area, although nearby control wells encountered basement at a depth of only about $2 \mathrm{~km}$. A rapid change in basement density may be the cause of this inversion instability. To rectify the problem, the geology in the nearby constraining drill holes was projected to the site of the fictitious well, leading to an estimated $2.5 \mathrm{~km}$ to basement. 
In this iterative approach, a first approximation of the basement gravity field is derived from those gravity measurements made on exposed pre-Cenozoic rocks (blue circles, fig. 4), augmented by basement gravity values calculated at sites where depth to basement is known (or estimated) and where variation of density with depth for the Cenozoic deposits is assumed. This field, an approximation because the gravity effects of nearby basins are ignored, is subtracted from the observed gravity, which provides the first approximation of the basin gravity field. Using an assigned density-depth relationship, the thickness of the basin-filling deposits is calculated. The gravitational effect of this first approximation of the basin-filling layer is computed at each known basement station. This effect is subtracted from the first approximation of the basement gravity field and the process is repeated until the change in basin thickness and thus basement gravity is negligible.

Because the study area has a complex tectonic history, leading to complex geology and thus to a wide variation in subsurface densities, we were forced to use more than one depth-density relationship (fig. 5) to adequately represent the lateral change in geology (thus density) that is input to the modeling process. These changes in geology include thick low-density volcanic rocks in the Silent Canyon caldera complex (such as beneath Pahute Mesa), dense volcanic rocks related both to a resurgent dome in the Timber Mountain caldera complex and to cap rocks of welded tuffs in the Rainier Mesa area, and locally low-density sedimentary and volcanic rocks in the Yucca Flat area. These four local depth-density relationships are shown in figure 5 and discussed in the next section. This is an improvement over previous work because it incorporates lateral changes in the density-depth relationship, a factor not taken into account by Hildenbrand and others (1999), McKee and others (1999), and Phelps and others (1999). Furthermore, the density-depth relationships incorporated into this model are based on an extensive literature search that resulted in greater detail being incorporated into the vertical changes in the density-depth relationships.

In the calculation of the isostatic residual gravity anomaly, rock mass above sea level was assumed to have a density of $2,670 \mathrm{~kg} / \mathrm{m}^{3}$. This estimated reduction density is probably appropriate for areas where the near-surface layer consists chiefly of pre-Cenozoic rocks (e.g., along the Eleana Range). However, in areas with volcanic and sedimentary rocks in the near-surface layer (average density generally between 2,100 and $2,400 \mathrm{~kg} / \mathrm{m}^{3}$ ), the 
basin analysis method described above will overestimate basin thicknesses. For example, the change in elevation between Pahute Mesa (where the average density of the rocks above sea level is roughly $2,200 \mathrm{~kg} / \mathrm{m}^{3}$ as discussed below) and the Eleana Range (where Paleozoic rocks with a represented density of $2,670 \mathrm{~kg} / \mathrm{m}^{3}$ are exposed) is about $300 \mathrm{~m}$ (fig. 6). The anticipated overestimate in relative basement depth or basin thickness, related to an erroneously high reduction density at Pahute Mesa, is roughly $700 \mathrm{~m}(2,300$ $\mathrm{ft})$ in our final results.

\section{Generalized density-depth Functions}

The accuracy of the basin thickness calculations is highly dependent on the assumed density-depth relationship of Cenozoic rocks and the initial density assigned to basement rocks. Cenozoic rocks are almost entirely of volcanic origin in this area, although thin alluvial deposits are found locally. Several factors complicate the task of selecting representative densities at a particular depth: the degree of welding and alteration of the ash-flow tuffs; structural complexities due to, for example, landslides and shallow, dense volcanic domes, and volcanic ponding; and water saturation. Because density generally increases with depth in drill hole data due to compaction, a horizontally layered density model is assumed for the Cenozoic deposits, although the lenticular nature of the volcanic rocks is acknowledged.

The density-depth relationship for the entire Nevada Test Site and surrounding regions (partially shown as the regional area in fig. 5; Hildenbrand and others, 1999) was modified with more local density-depth relationships based on previous studies of Pahute Mesa (McKee and others, 1999) and Yucca Flat (Phelps and others, 1999). For our study, new density-depth relationships were developed for the Timber Mountain and Rainier Mesa areas utilizing density and drill hole data provided by Kane and others (1981) and Carroll (1989), respectively.

\section{Regional area}

The regional density-depth relationship for Cenozoic basin fill in table 1 (fig. 5) adopts the same depth intervals used by Jachens and Moring (1990) in compiling a Nevada Cenozoic basin thickness map. However, densities within the various zones $(1,900$, 2,100, 2,300 and 2,450 kg/m ${ }^{3}$ ) used by Hildenbrand and others (1999) are somewhat lower than the ones used by Jachens and Moring (1990) for exposed volcanic rock 
$\left(2,220,2,270,2,320\right.$ and 2,420 kg/m $\left.{ }^{3}\right)$ and sedimentary rock $(2,020,2,120,2,320$ and $\left.2,420 \mathrm{~kg} / \mathrm{m}^{3}\right)$. Due to their limited study area compared to the entire state of Nevada, Hildenbrand and others (1999) argued that the density data in their study area leads to a single regional density-depth function adequately representing terranes with both volcanic and sedimentary rocks at the surface. Although this generalized relationship may be a reasonable approximation for the large region used by Hildenbrand and others (1999) (from lat. $36^{\circ} 30^{\prime}$ to $37^{\circ} 30^{\prime}$ and from long. $115^{\circ} 52.2^{\prime}$ to $117^{\circ}$ ), it may lead to significant errors in more local areas.

\section{Yucca Flat, Timber Mountain, and Pahute Mesa areas}

More detailed basin studies in local areas like Yucca Flat show that revisions to the regional density-depth relationship yield better results when existing drill hole information is available to revise the density-depth relationship and provide constraints on the inversion analyses. Published borehole gravity data for nine wells within Yucca Flat provided information on the change of density with depth within Yucca Flat basin (see Phelps and others, 1999). A graph of the depth versus density of the basin sediments and volcanic rocks within Yucca Flat shows a linear trend that increases with depth. Phelps and others (1999) fitted a linear regression to the data, leading to a depth-density relationship with five depth intervals: 0-200, 200-400, 400-600, 600-800, and >800 m (fig. 5).

Based on density data from Kane and others (1981), another generalized depth-density relationship is warranted for the resurgent dome of the Timber Mountain caldera complex. Although only a small portion of the dense dome defined by a pronounce gravity high lies within the study area, a different density-depth relationship is included here for completeness. Also, it should be noted that all calculations were made over an area much larger than that shown in figure 5, and thus a more complete model using a Timber Mountain depth-density relationship is useful in more regional studies of the northern NTS. Kane and others (1981) concluded that a density of $2,400 \mathrm{~kg} / \mathrm{m}^{3}$ is generally applicable in the immediate vicinity of Timber Mountain or the resurgent dome

where densely welded tuffs and intrusive rhyolites are found. Thus a 2,400 kg/m $\mathrm{m}^{3}$ density was used for the layers above pre-Cenozoic rocks (fig. 5) in an area defined by a gravity high over the Timber Mountain resurgent dome. Kane and others (1981) also mentioned that a lower density of $2,200 \mathrm{~kg} / \mathrm{m}^{3}$ represents volcanic rocks in the moat of the Timber 
Mountain caldera complex and beyond, which agrees with the density proposed by Hildenbrand and others (1999) for shallow volcanic units (fig. 5).

Low-density tuff layers are observed in the Silent Canyon caldera complex such as beneath Pahute Mesa. Borehole gravimeter studies (Ferguson and others, 1994; Warren and other, 1999) reveal densities of $2,100 \mathrm{~kg} / \mathrm{m}^{3}$ extending in many areas to depths of more than $1,000 \mathrm{~m}$. In such situations, calculated basement depths using the regional depth-density relationship will be overestimated. Thus in generating a Cenozoic thickness map, McKee and others (1999) used a different density-depth relationship based on a careful analysis of the density data from Warren and others (1999). They showed that below $600 \mathrm{~m}$ the basin fill within the Silent Canyon caldera complex is less dense than the rocks outside the caldera, resulting in the density model shown in table 1 (fig. 5) for Pahute Mesa.

\section{Rainier Mesa}

Carroll (1989) provided an excellent study and review of known density measurements in the Rainier Mesa area, which leads to a wealth of data justifying variation of the regional density-depth relationship. The primary data sets are density logs from 10 drill holes and core density measurements from 10 other wells. For this area, the volcanic rocks overlying pre-Cenozoic basement range from densely-welded tuffs to friable and vitric ash-flow tuffs. Carroll (1989) noted a density boundary ( $200 \mathrm{~kg} / \mathrm{m}^{3}$ density change) at the top of the zeolitization zone, separating unsaturated tuffs from underlying denser saturated zeolitized ash-fall and ash-flow tuffs. An overall recurring depth-density relationship of the volcanic section is a thin dense cap rock of either welded Rainier Mesa or Belted Range tuff (Grouse Canyon Member), low-density unsaturated nonwelded volcanic rocks, moderately-dense zeolitized bedded tuffs, denser welded tuffs, and preCenozoic basement. In Carroll (1989), generalized density boundaries emerge when carefully analyzing the data in his table 2 listing representative densities for several lithologic units, in his figures 9-11 showing lithologic and density logs, and in his figures 8 and 18-22 showing histograms of density logs for individual lithologic units. Representative densities based on his data are $2,200 \mathrm{~kg} / \mathrm{m}^{3}$ for the cap rock in a $75 \mathrm{~m}$ surface interval, $1,700 \mathrm{~kg} / \mathrm{m}^{3}$ for the underlying nonwelded volcanic rocks that are roughly $125 \mathrm{~m}$ thick, and $1,900 \mathrm{~kg} / \mathrm{m}^{3}$ for the zeolitized tuffs extending from about 200 to $600 \mathrm{~m}$. Beneath a depth of about $600 \mathrm{~m}$, density for the older welded tuffs significantly 
increases to roughly $2,300 \mathrm{~kg} / \mathrm{m}^{3}$. Because of the limited information on density for deeper units, we assumed compaction led to an increased density of 2,450 kg/m at 1,200 $\mathrm{m}$, which are values that match most of the density-depth relationships (table 1 in fig. 5) based on the work of others. The boundary shown in figure 5 for the Rainier Mesa density-depth relationship was first drawn around an area encompassing outcrops of the Rainier Mesa and Belted Range tuffs. This boundary was necessarily modified so that the results of the modeled thickness of Cenozoic deposits in the Rainier Mesa area matched the results of neighboring areas (discussed below).

\section{Composite Thickness Map and Resulting Accuracy}

Using the gravity inversion method derived by Jachens and Moring (1990; modified to include drill hole data), we separated the isostatic residual gravity anomaly into a basin gravity field and a basement gravity field using each of the depth-density relationships in table 1 (fig. 5). The basin gravity fields for the five depth-density relationships reflect variations in the thickness of low-density Cenozoic volcanic and sedimentary rocks and were used to generate a basin thickness map shown in figures 7 and 8 . The gravity inversion model is thus the result of several modeling stages in which the different density-depth relationships were used to optimize the thickness model to local changes in general geology. In the inversion process, the density of basement was allowed to vary horizontally but the density of basin-filling deposits is fixed using the five representative density versus depth relationships (table 1 in fig. 5). This resulted in five Cenozoic thickness data sets based on the five density-depth relationships. To generate a composite thickness map shown in figures 7 and 8, the results within each of the areas shown in figure 5 were merged to adjacent thickness results. For the Yucca Flat and Rainier Mesa areas, their boundaries were determined by selecting a line where their thickness agreed with adjoining modeling results. For the Pahute Mesa and Timber Mountain areas, a 2-km-wide buffer zone was generated where thicknesses were masked and then filled in using a minimum curvature algorithm so that a smooth transition in thickness occurred across adjoining density-depth models. Thus the final composite thickness model obeys the density-depth relationships for the five areas, and also the thickness results across boundaries between the various area models are smooth. 
The accuracy of these results varies due primarily to the necessary step of oversimplifying the density-depth relationships. In regions where good basement control exists (either from basement outcrops or well data, fig. 4) the results are probably within roughly $300 \mathrm{~m}$ as discussed below (e.g., the Eleana Range and Yucca Flat areas). The expected variability in local density-depth functions and the lack of basement control in some areas (e.g., the Silent Canyon caldera complex and Timber Mountain caldera complex) strongly argue that the relative change in basin thickness rather than its magnitude should be stressed in studying the basement surface.

The data from the 14 constraining drill holes bottoming in old volcanic rocks (green circles, figs. 4 and 8), however, offer an opportunity to study the accuracy of the thickness results by carrying out the inversion analysis with and without the use of these data. Comparison of the results at these drill holes reveals that at 5 locations (labeled in fig. 4), pre-Cenozoic basement was determined to be shallower than the Micocene volcanic rocks at the bottom of the drill holes. The gravity inversion model is underpredicting the basement depth at these locations. The differences between depth to the bottom of these 5 holes and calculated depth to basement ranged from 18 to $127 \mathrm{~m}$ and averaged $50 \mathrm{~m}$. The actual basement probably lies roughly between 200 and $400 \mathrm{~m}$ below the bottom of these drill holes (Ted McKee, U.S. Geological Survey, oral communication, 2006). The gravity inversion model therefore underpredicts basement depth at these 5 locations by between about 250 and $450 \mathrm{~m}$. The calculated depths to preCenozoic basement for the remaining 9 constraining drill holes were between $34 \mathrm{~m}$ and $623 \mathrm{~m}$ deeper than the depths to the bottom of the drill holes, averaging $232 \mathrm{~m}$. Since these wells encountered volcanic units of similar age, we can conclude that the gravity inversion model is more accurate at these 9 drill-hole locations. In general we conclude from this analysis that in areas of good basement depth control from outcrops and drills holes that encountered pre-Cenozoic rocks (e.g., the general area of the 14 constraining drill holes; fig. 4), the inversion accuracy is approximately $300 \mathrm{~m}$.

\section{Discussion}

An improved basement depth map of the Rainier Mesa area was produced and is intended for use in 3D hydrogeologic modeling. In areas of good well control the accuracy of the depth results is roughly $300 \mathrm{~m}$, based on the analysis discussed in the previous section. 
On the other hand, accuracies deteriorate away from outcrop and well control, and in areas where basement deepens, the accuracy of results become more suspect. With these caveats and the previously described accuracy limitations in mind, we discuss the complex nature of the basement surface, clearly evident in figures 7 and 8 . In general, the pre-Cenozoic basement surface deepens over $4 \mathrm{~km}$ to the west in the collapse calderas and shallows to the east in the Eleana Range and toward Yucca Flat, where basement crops out. In the Rainier Mesa region, basement is generally shallow $(<1 \mathrm{~km})$. This corresponds, to some extent, with the intrusion of the Gold Meadows stock, which forms a broad dome roughly $5 \mathrm{~km}$ in diameter intruding Rainier Mesa (fig. 8).

An interesting aspect of the northern portion of the study area is the presence of a buried ridge that extends from the Gold Meadows stock northward into Kawich Valley. Its linearity and proximity to the Gold Meadows stock may suggest a dike origin during Tertiary volcanism. On the other hand, this previously unrecognized structure roughly parallels the Belted Range thrust to the east (fig. 8) and may be associated with older faulting. It extends northward along the eastern flank of Kawich Valley (fig. 6). Just east of this ridge in Kawich Valley, the gravity inversion indicates the presence of a deep basin $(>5 \mathrm{~km})$. The subsurface ridge-and-basin structure could be indicative of a zone of previous thrust faulting during Mesozoic time associated with the Belted Range thrust. On trend with the interpreted ridge, and about $6 \mathrm{~km}$ north of the study area (highlighted in fig. 1), Cambrian rocks crop out and support the northward extension of the basement ridge and a relationship to faulting. Conceivably, erosion of Paleozoic and Mesozoic rocks and stresses related to flexure resulted in a basin forming in front of the thrust fault, which is now covered with a thick volcanic pile. However, Mesozoic thrust faulting generally juxtaposed pre-Cenozoic rocks of similar density, and a near-surface, local gravity anomaly associated with these thrusts is thus not anticipated but is observed along the interpreted ridge. For example, the Belted Range thrust fault (fig. 2) produces a large regional gradient (fig. 2) but not a local effect like the anomaly associated with the ridge (fig. 2). An alternative fault-related hypothesis for the buried ridge and associated basin is that these features formed as part of the Basin and Range extension, although the ridge appears to extend southward past the limit of the southern end of Kawich Valley. 
Whatever the origin of the ridge, it may have implications for ground-water flow.

Southward inflow to the NTS from Kawich Valley and Gold Flat is the largest source of ground water into the Pahute Mesa and Rainier test areas (Blankennagel and Weir, 1973). The interpreted ridge striking SSW from Kawich Valley to Rainier Mesa (and possibly beyond) may represent a major barrier and/or conduit (e.g., Rowley, 1998; Mankinen and others, 2003) resulting in a southward channeling of groundwater into the NTS.

Prominent depressions ( $>4 \mathrm{~km}$ ) in basement occur between the calderas and Rainier Mesa and are highlighted with question marks in Figures 7 and 8. We have no explanation for their origins other than they may be related to caldera formation and thus could delineate areas of significant accumulations of low-density volcanic rocks.

\section{References}

Armstrong, R.L., 1968, Sevier orogenic belt in Nevada and Utah: Geological Society of American Bulletin, v. 79, p. 429-459.

Blankennagel, R.K., and Weir, J.E., Jr., 1973, Geohydrology of the eastern part of Pahute Mesa, Nevada Test Site, Nye County, Nevada: U.S. Geological Survey Professional Paper 712-B, 35 p.

Christiansen, R.L., Lipman, P.W., Carr, W.J., Byers, F.M., Jr., Orkild, P.P., and Sargent, K.A., 1977, The Timber Mountain-Oasis Valley caldera complex of southern Nevada: Geological Society of America Bulletin, v. 88, p. 943-959.

Carroll, R.D., 1989, Density logging and density of rocks in the Rainier Mesa area, Nevada Test Site: U.S. Geological Survey Open-File Report 89-329, 72 pp.

Ferguson, J.F., Cogbill, A.H., and Warren, R.G., 1994, A geophysical-geological transect of the Silent Canyon caldera complex, Pahute Mesa, Nevada: Journal of Geophysical Research, v. 99, p. 4323-4339.

Grauch, V.J.S., Sawyer, D.A., Fridrich, C.J., and Hudson, M.R., 1999, Geophysical framework of the southwestern Nevada volcanic field and hydrogeologic implications: U.S. Geological Survey Professional Paper 1608, 39p.

Healey, D.L., 1968, Application of gravity data to geologic problems at Nevada Test Site, in Eckel, E.B., ed., Nevada Test Site: Geological Society of America Memoir 110, p. 147-156.

Hildenbrand, T. G., Langenheim, V. E., Mankinen, E. A., and McKee, E. H., 1999, Inversion of gravity data to define the pre-Tertiary surface of the Pahute MesaOasis Valley region, Nye County, Nevada, Open-File Report, OF 99-0049, 29p.

Jachens, R.C., and Moring, B.C., 1990, Maps of the thickness of Cenozoic deposits and the isostatic residual gravity over basement for Nevada: U.S. Geological Survey Open-File Report 90-404, 15 p.

Kane, M.F., Webring, M.W., and Bhattacharyya, B.K., 1981, A preliminary analysis of gravity and aeromagnetic surveys of the Timber Mountain area, southern Nevada: U.S. Geological Survey, Open-File Report 81-189, 40p. 
Kersting, A.B., Efurd, D.W., Finnegan, D.L., Rokop, D.J., Smith, D.K., and Thompson, J.L., 1999, Migration of plutonium in ground water at the Nevada Test Site: Nature, v. 397, p. 56-59.

Laczniak, R.J., Cole, J.C., Sawyer, D.A., and Trudeau, D.A., 1996, Summary of hydrogeologic controls on ground-water flow at the Nevada Test Site, Nye County, Nevada: U.S. Geological Survey Water-Resources Investigations Report 96-4109, 59p.

Mankinen, E.A., Hildenbrand, T.G., Fridrich, C.J., McKee, E.H., and Schenkel, C.J., 2003, Geophysical setting of the Pahute Mesa-Oasis Valley region, southern Nevada: Nevada Bureau Mines \& Geology Report 50, CD-ROM, 45 p.

Mankinen, E.A., Hildenbrand, T.G., Roberts, C.W., and Davidson, J.G., 1998, Principal facts for new gravity stations in the Pahute Mesa and Oasis Valley areas, Nye County, Nevada: U.S. Geological Survey Open-File Report 98-498, 14p.

McKee, Edwin H., Hildenbrand, Thomas G., Anderson, Megan L., Rowley, Peter D., Sawyer, David A., 1999, The Silent Canyon caldera complex; a three-dimensional model based on drill-hole stratigraphy and gravity inversion, Open-File Report, OF 99-0555, 79p.

Morelli, Carlo, Gantar, C., Honasala, Taunao, McConnel, R.K., Tanner, J.G., Szabo, Bela, Uotila, U.A., and Whalen, G.T., 1974, The International Gravity Standardization Gravity Net 1971 (I.G.S.N. 71): Paris Bureau Centrale de l'Association Internationale de Geodesie Special Publication 4, 193p.

Nobel, D.C., Weiss, S.I., and McKee, E.H., 1991, Magmatic and hydrothermal activity, caldera geology, and regional extension in the western part of the southwestern Nevada volcanics field: in, Raines, G.L., Lisle, R.E., Schafer, R.W., and Wilkinson, W.H., eds., Geology and Ore Deposits of the Great Basin, Geological Society of Nevada, Reno, Nevada, P. 913-934.

Phelps, G.A., Langenheim, V.E., and Jachens, R.C., 1999, Thickness of Cenozoic deposits of the Yucca Flat, Nevada Test Site, Nevada, inferred from gravity data: U.S. Geological Survey Open-File Report 99-310, 29p.

Rowley, P.D., 1998, Cenozoic transverse zones and igneous belts in the Great Basin, western U.S. -- Their tectonic and economic implications, in Faulds, G.E., and Stewart, J.H., eds., Accommodation Zones and Transfer Zones - The Regional Segmentation of the Basin and Range Province: Geological Society of America Special Paper 323, p. 195-228.

Russell, G.M., and Locke, G.L., 1996, Summary of data concerning radiological contamination at well PM-2, Nevada Test Site, Nye County, Nevada: U.S. Geological Survey Open-File Report 96-599, 84 p.

Sawyer, D.A., Fleck, R.J., Lanphere, M.A., Warren, R.G., Broxton, D.E., and Hudson, M.R., 1994, Episodic caldera volcanism in the Miocene southwestern Nevada volcanic field: Revised stratigraphic framework, ${ }^{40} \mathrm{Ar} /{ }^{39} \mathrm{Ar}$ geochronology, and implications for magmatism and extension: Geological Society of America Bulletin, v. 106, p. 1304-1318.

Slate, Janet L., Berry, Margaret E., Rowley, Peter D., Fridrich, Christopher J., Morgan, Karen S., Workman, Jeremiah B., Young, Owen D., Dixon, Gary L., Williams, Van S., McKee, Edwin H., Ponce, David A., Hildenbrand, Thomas G., Swadley, W. C., Lundstrom, Scott C., Ekren, E. Bartlett, Warren, Richard G., Cole, James C., Fleck, Robert J., Lanphere, Marvin A., Sawyer, David A., Grunwald, Daniel J., Laczniak, Randell J., Menges, Christopher M., Yount, James C., Jayko, Angela 
S., 1999, Digital geologic map of the Nevada Test Site and vicinity, Nye, Lincoln, and Clark counties, Nevada, and Inyo County, California, revision 4: Open-File Report, OF 99-0554-A, p. (1 sheet).

Simpson, R.W., Jachens, R.C., Blakely, R.J., and Saltus, R.W., 1986, A new isostatic residual gravity of the conterminous United States, with a discussion of the significance of the isostatic residual anomalies: Journal of Geophysical Research, v. 91 , p. $8348-8372$.

U.S. Department of Energy, 1994, United States nuclear tests July 1945 through September 1992: U.S. Department of Energy, Nevada Operation Office, DOE/NV-209 (rev. 14), 105 p.

Warren, R.G., Sawyer, D.A., Byers, F.M., Jr., and Cole, G.L., 1999, A petrographic/geochemical database and structural framework for the soitherwestern Nevada volcanic field: National Geophysical Data Center, http://qeeg.ngdc.gov/seg/geochem/swnvf or ftp://ftp.ngdc.noaa.gov/Solid-Earth/Geochem/SWNVF.

Webring, Michael, 1982. MINC--A gridding program based on minimum curvature: U.S. Geological Survey Open-File Report 81-1224, 43 p. 


\section{Figures}

Figure 1. Topographic map of the northern Nevada Test Site (NTS). Black lines represent caldera structural boundaries as drawn by Slate and others (1999). Red line shows study area used in the remaining figures. Green areas denote pre-Cenozoic outcrops. Small black circle in the southeastern Kawich Valley highlights an outcrop discussed in the text.

Figure 2. Isostatic residual gravity anomaly field of the Rainier Mesa region. Anomalies express to first order the average density of the middle and upper crust. PreCenozoic outcrops highlighted with heavy white lines. Light dashed white lines show roads.

Figure 3. Location of gravity stations. Black circles denote existing stations and magenta circles represent stations newly acquired for this study. Red lines show boundaries of pre-Cenozoic outcrop. Purple thin lines show roads.

Figure 4. Drill-hole and outcrop constraints used in the inversion process. Yellow circles denote wells that encountered pre-Cenozoic basement. Green circles locate constraining drill holes that bottomed in older volcanic rocks above basement but provide estimates of basement depth using expected stratigraphy and unit thicknesses. Selected drill holes numbered (1-5) are discussed in text. Two green circles with a white $\mathrm{X}$ are locations where depth to basement was pinned using expected unit thicknesses from known geology. Red lines show boundaries of pre-Cenozoic outcrop. Blue circles locate gravity stations on basement outcrop.

Figure 5. Assumed density-depth relationships in separate areas within the Rainier Mesa study area. Labeled blue areas define local density-depth relationships that deviate from the regional density model (white areas). Depth-density relationships for each area shown in the table 1.

Figure 6. Topography of the Rainier Mesa region. Roads shown in blue.

Figure 7. Three-dimensional shaded view of the pre-Cenozoic surface beneath the Rainier Mesa region. Question marks highlight deep basins outside caldera boundaries of unknown origin. Interpreted ridge in northern part of study area is shown. 
Figure 8. Thickness of Cenozoic deposits based on the inversion of gravity data. Yellow lines highlight the mapped Belted Range thrust fault and an interpreted ridge extending NNE from Rainier Mesa into Kawich Valley (dashed where inferred). Question marks locate a few deep basins outside caldera boundaries of unknown origin. White and green circles identify pre-Cenozoic basement wells and constraining wells, respectively. White lines show roads. 
Fig. 1 Topography of the Northern NTS

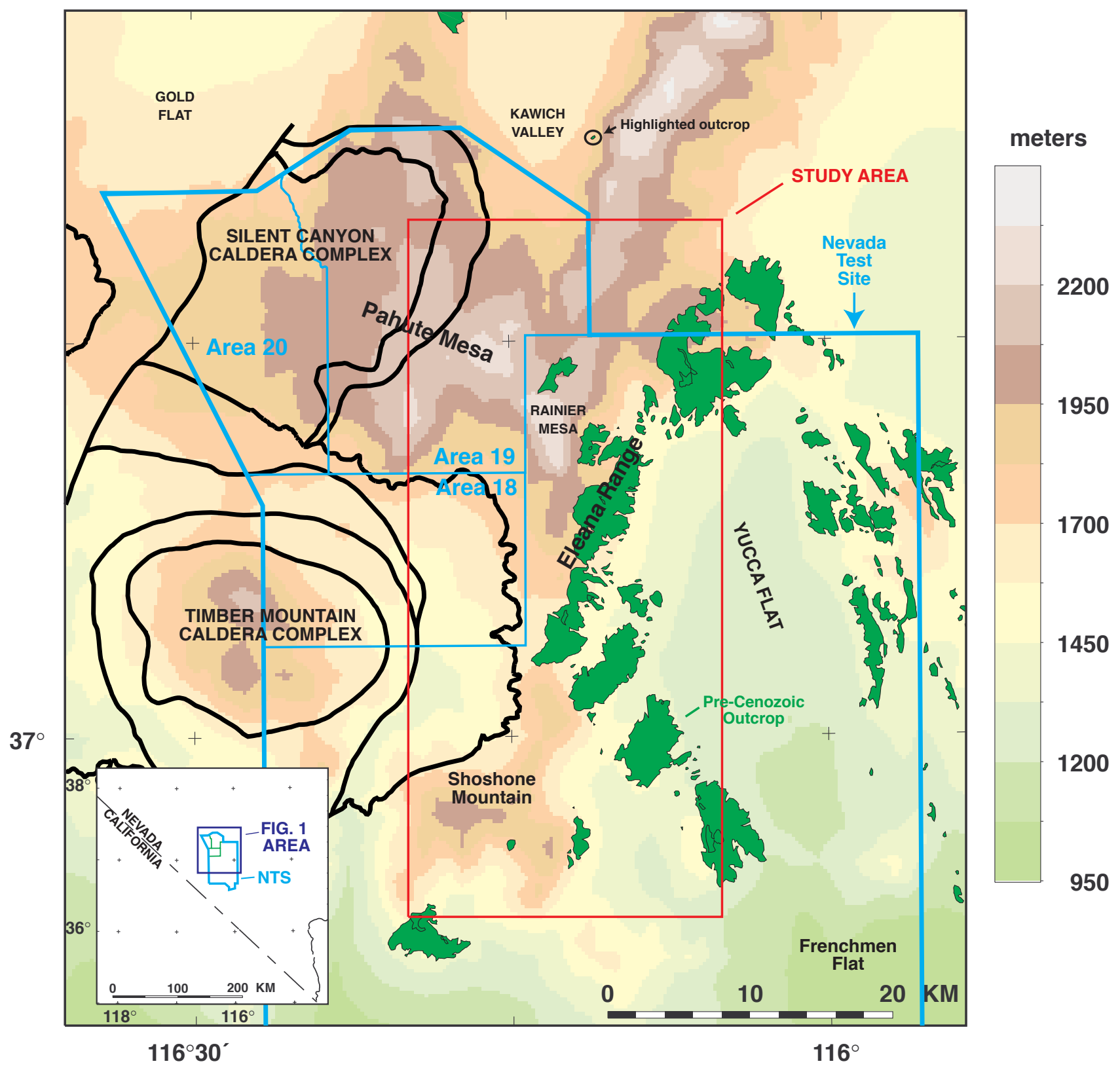


Figure 2. Isostatic Gravity Anomaly

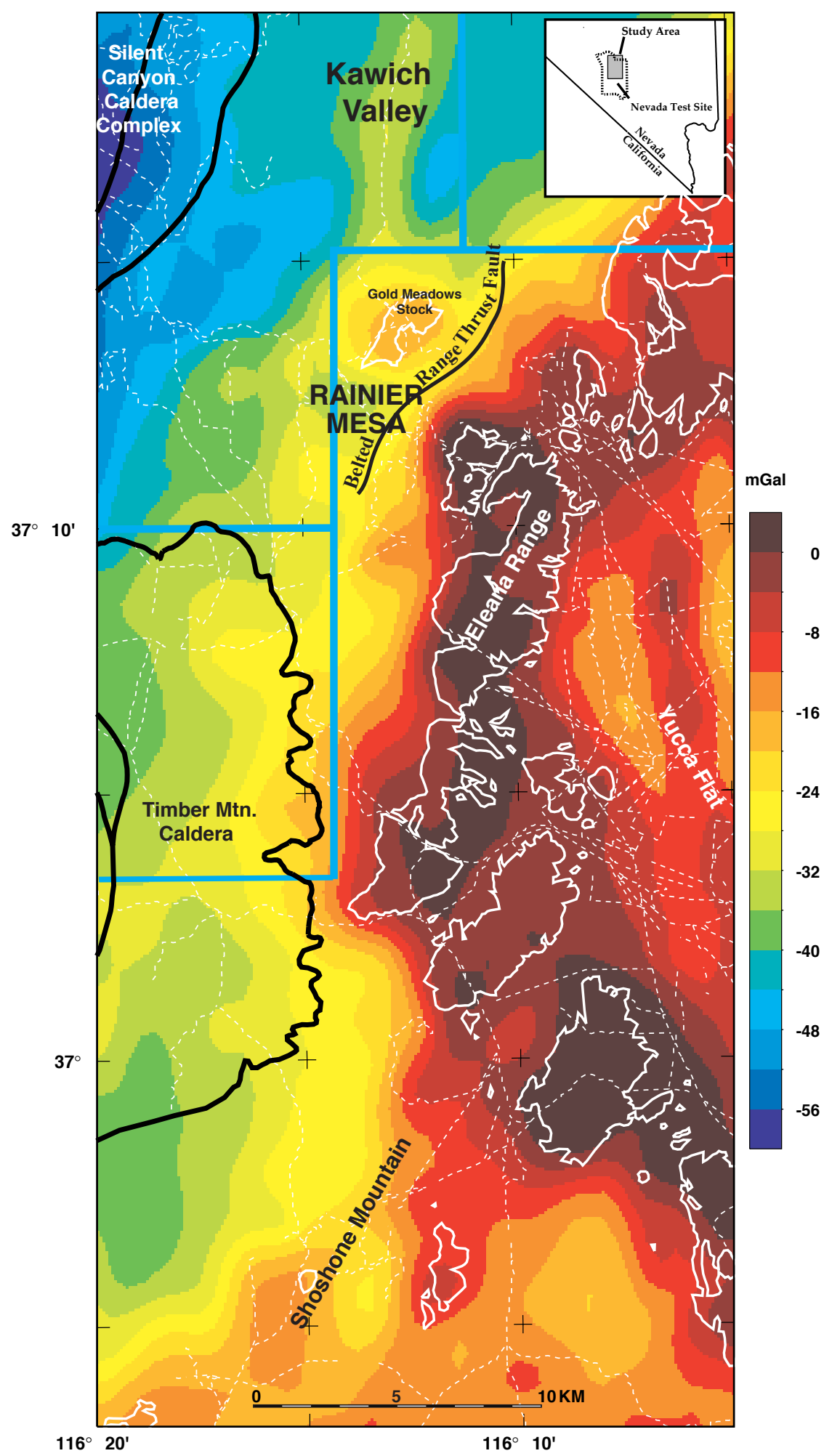


Fig. 3 Gravity Stations

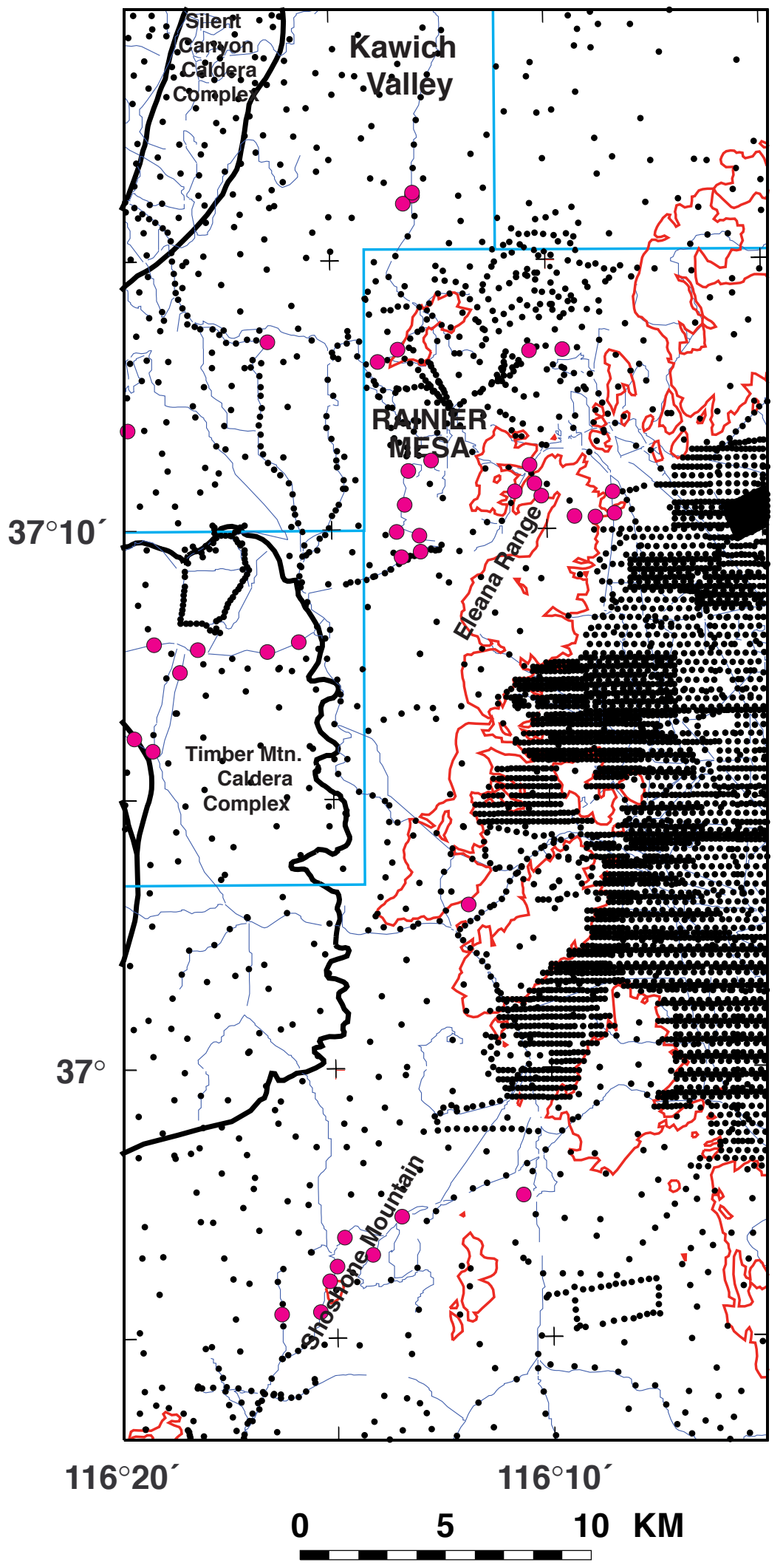


Fig. 4 Model Constraints

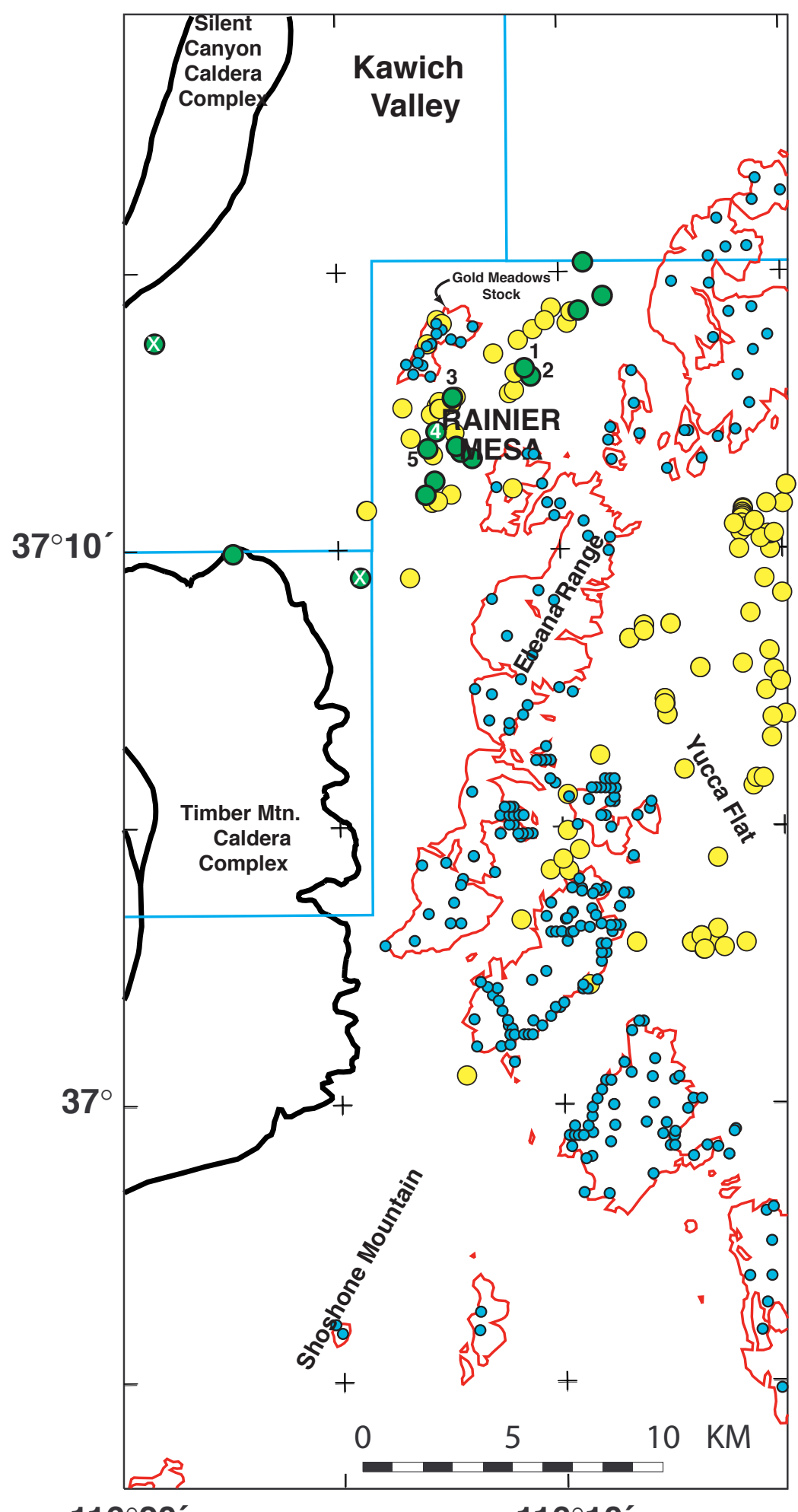

$116^{\circ} 20^{\prime}$

$116^{\circ} 10^{\prime}$ 
Fig. 5 Density-depth relationships

\begin{tabular}{|ccrrrr|}
\hline \multicolumn{5}{c}{$\begin{array}{c}\text { Table 1. Generalized density-depth functions used to } \\
\text { determine the thickness of Cenozoic deposits. }\end{array}$} \\
$\begin{array}{c}\text { Depth Range } \\
\text { (meters) }\end{array}$ & $\begin{array}{r}5 \\
\text { Regional }\end{array}$ & $\begin{array}{r}\text { Pensity }\left(\mathrm{kg} / \mathrm{m}^{3}\right) \\
\text { Pahute }\end{array}$ & Yucca 5 models & Rainier & Timber \\
$0-75$ & 1,900 & 1,900 & 1,820 & 2,200 & 2,400 \\
$75-200$ & 1,900 & 1,900 & 1,820 & 1,700 & 2,400 \\
$200-400$ & 2,100 & 2,000 & 1,940 & 1,900 & 2,400 \\
$400-600$ & 2,100 & 2,000 & 2,060 & 1,900 & 2,400 \\
$600-800$ & 2,300 & 2,100 & 2,180 & 2,300 & 2,400 \\
$800-1,200$ & 2,300 & 2,100 & 2,300 & 2,300 & 2,400 \\
$>1,200$ & 2,450 & 2,450 & 2,300 & 2,450 & 2,400 \\
\hline
\end{tabular}

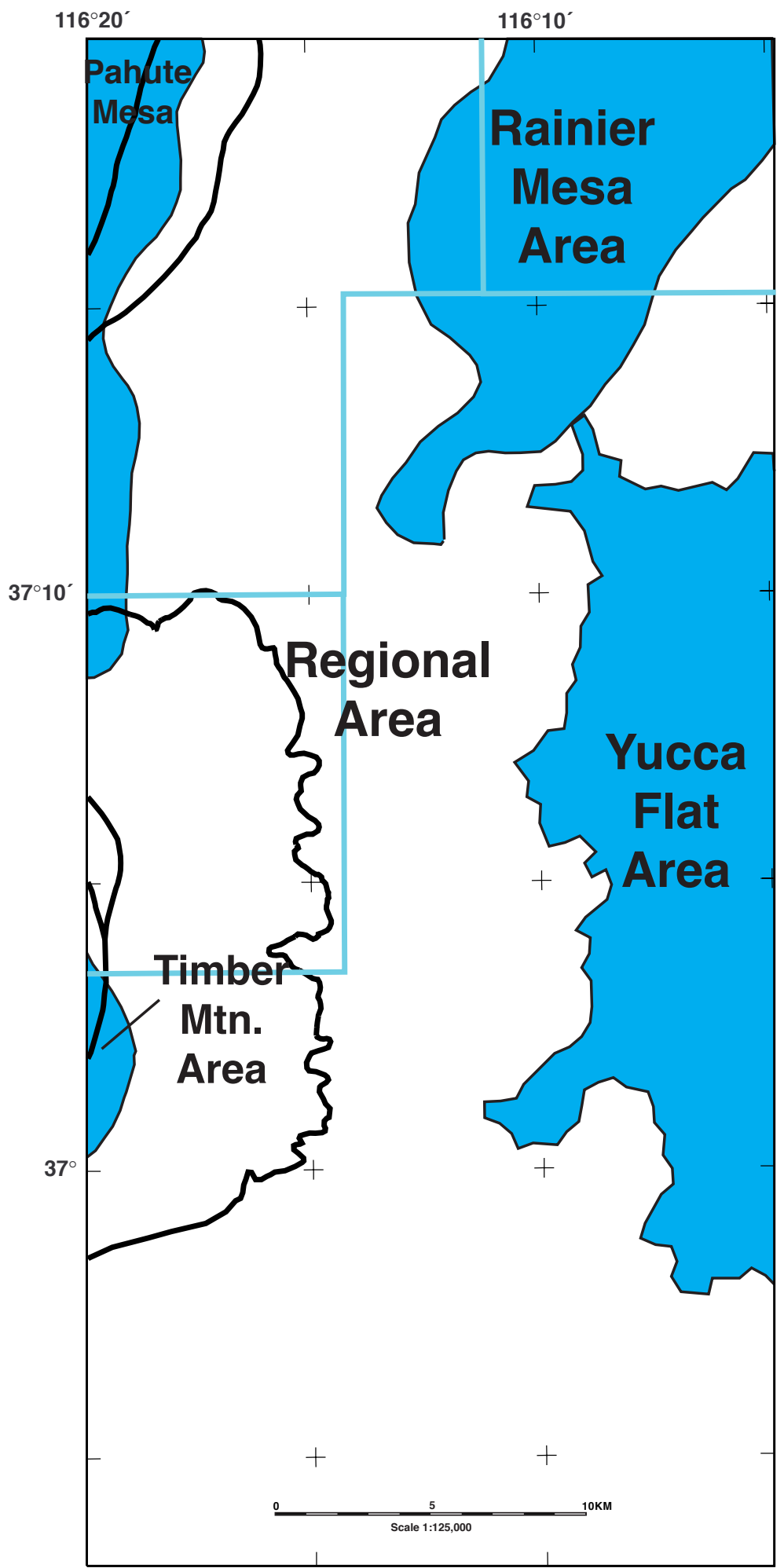


Fig. 6 Topography

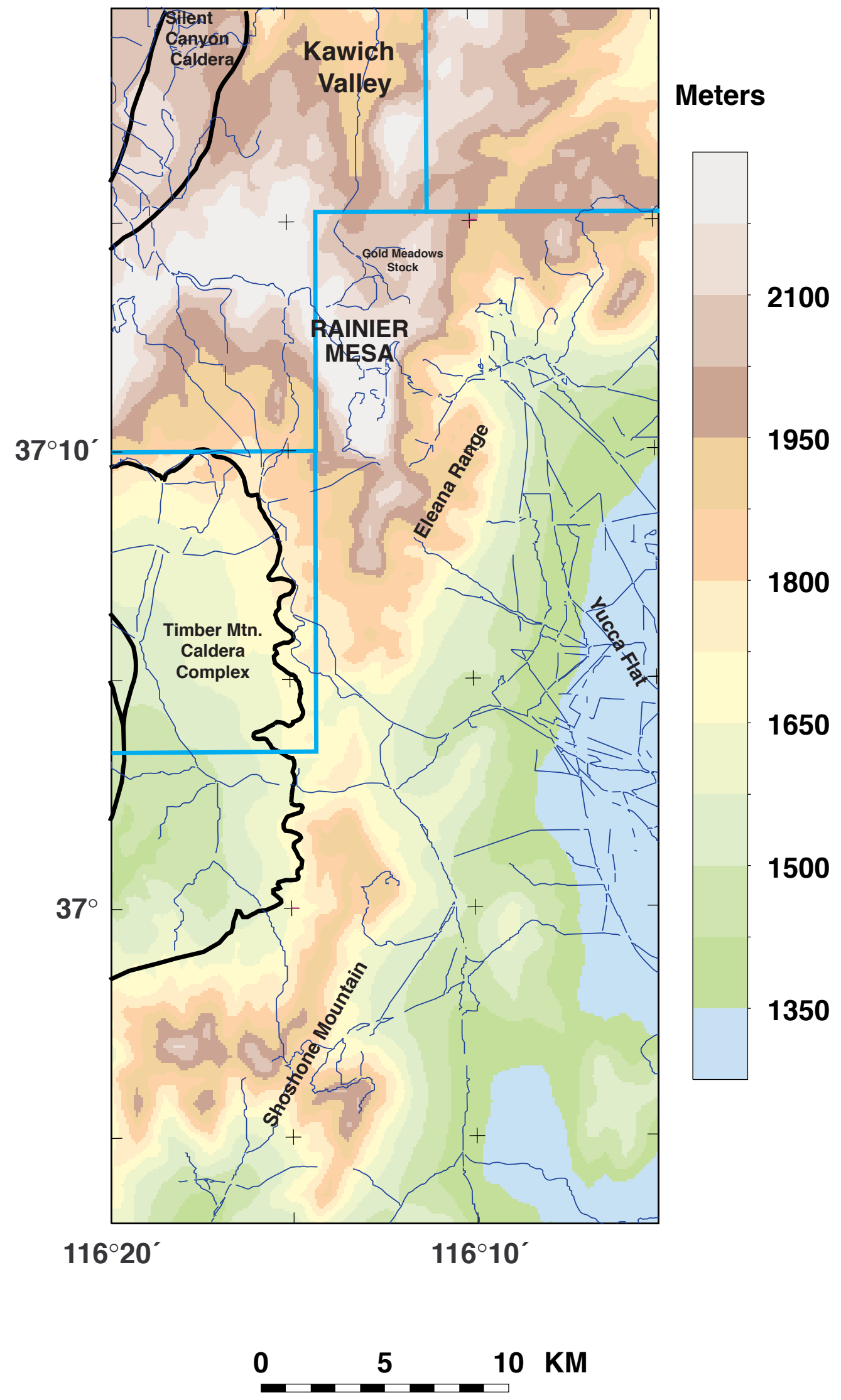


Figure 7. Three-dimensional view of the estimated basement thickness

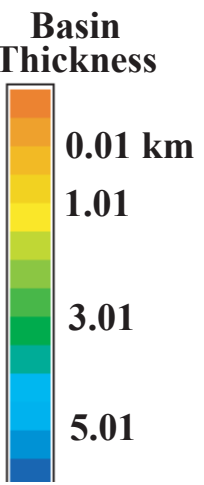

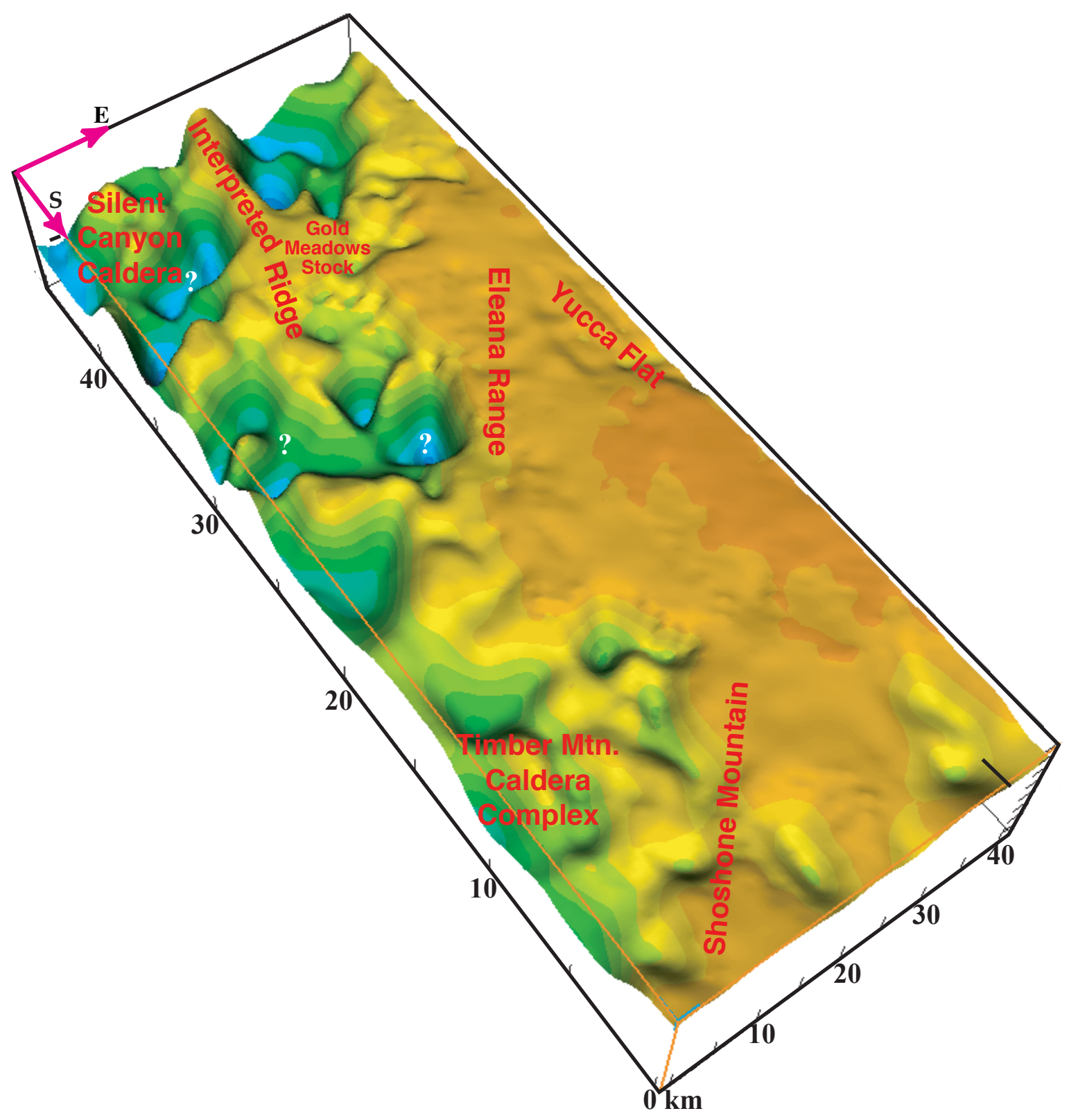


Fig. 8 Basin Thickness

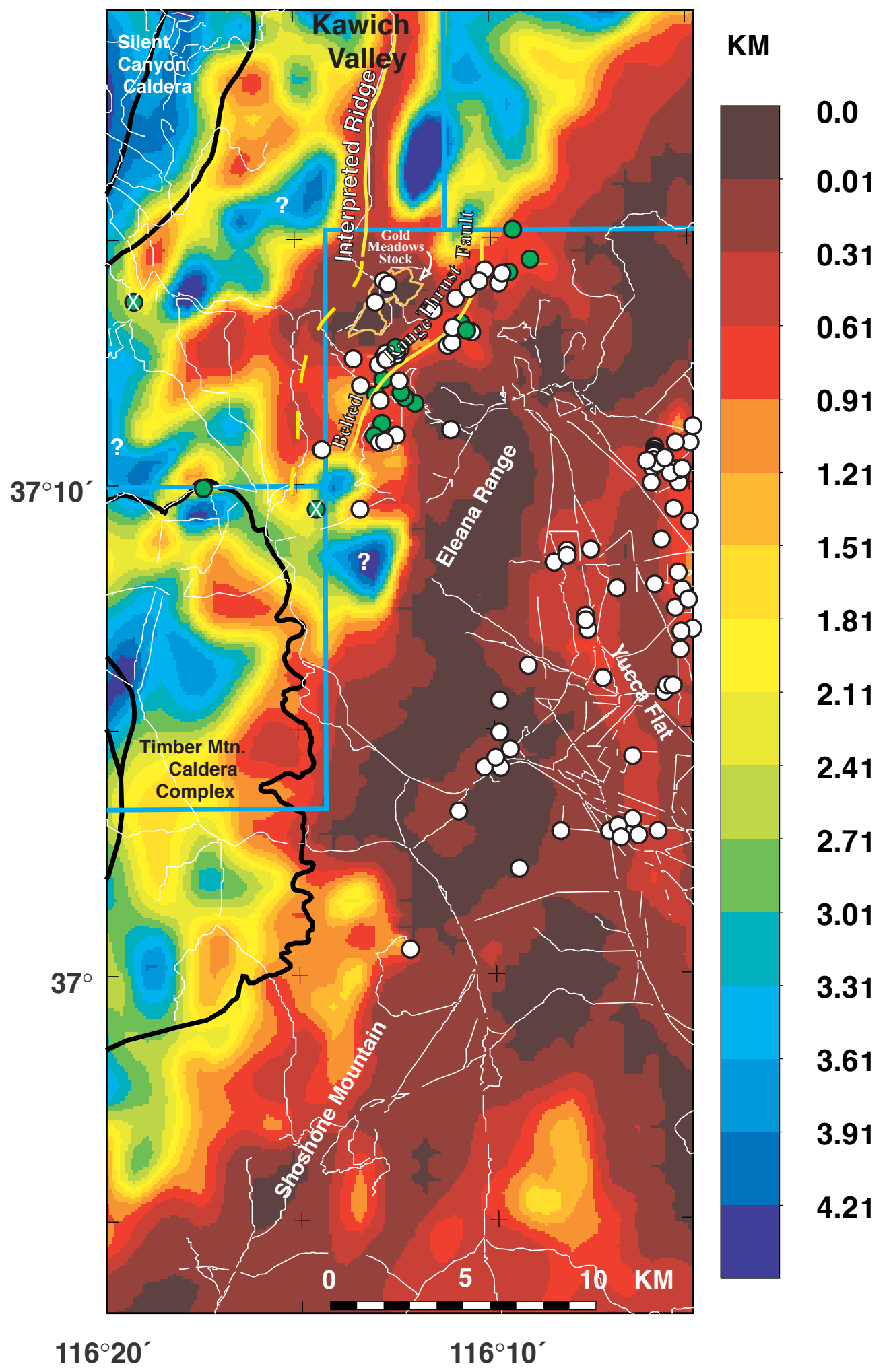

